\title{
Antagonistic Activity and Shelf Life Study of Trichoderma harzianum (Rifai)
}

\author{
D. Srinivasa Reddy*, Naveena Haritha and M. Pushpa Latha \\ Bio-Control Laboratory, Horticulture College and Research Institute, DRYSRHU, \\ Ananthrajupeta-516105, Koduru, Y.S.R. District, Andhra Pradesh, India \\ *Corresponding author
}

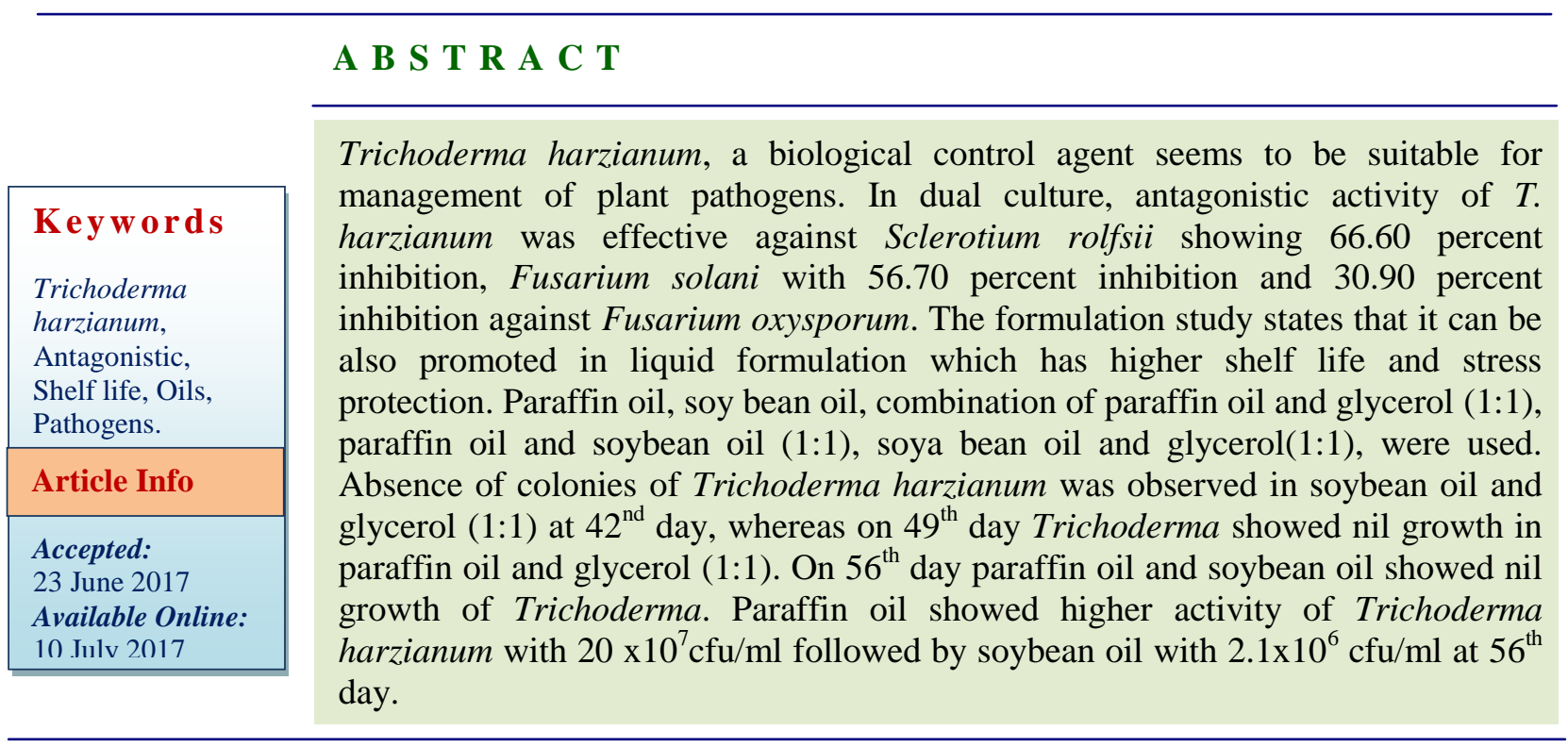

\section{Introduction}

Soil borne root infecting fungi are difficult to eradicate because they produce resting structure like sclerotia, chlamydospores or oospores for their survival for a longer period of time under adverse environmental conditions (Baker and Cooke, 1974). Use of fungicides for the control of soil borne diseases is costly and also produces environment and health hazards to men and adversely affects the beneficial microorganisms in soil (Dluzniewska, 2003). An alternative management should be given greater emphasis which is eco friendly, safe and effective than chemical methods. In this regard, use of Trichoderma harzianum, a biological control method seems to be suitable for management of the disease (Howell et al., 2000). Trichoderma is a biocontrol agent that has been widely used and reported effective against several fungi viz., Pythium (Naseby et al., 2000), Fusarium (Lewis and Papavizas, 1987), Rhizoctonia (Sivan and Chet, 1986), and Sclerotium (Jegathambigai et al., 2010). These pathogens cause diseases viz., damping off, wilt, root and collar rot and stem canker.

Trichoderma harzianum is present in all soils and other diverse habitats. They are better rhizosphere colonizers than plant pathogens, 
hence compete with other organisms for food and shelter there by reducing the chances of colonization by pathogenic fungi. Trichoderma have antifungal, antinematode, plant growth promoting and plant defense inducing activities (Zaidi et al., 2004). The commercial formulations of Trichoderma available in the market are talc based and there are also other formulations based on organic carriers such as neem cake, cow dung, tea waste, coffee husk (Bhai et al., 1994) sorghum grains (Sarma et al., 1998) etc. In talc based formulations, the viability of the spores are less and cfu decreases with increase in storage period.

Even though organic carrier based formulations maintain the viability of spores, they are always prone to spoilage by insects and other microbes in the long term and moreover these formulations are too bulky and difficult to transport in large quantities. In general, the major obstacle to the commercialization of such products is the development of a shelf-stable formulated product that retains biocontrol activity similar to that of the fresh product (Janisiewicz and Jeffers, 1997). Hence, study was initiated to test the spore viability of Trichoderma harzianum in different oils and its antagonistic activity.

\section{Materials and Methods}

\section{Bioefficacy}

The three soil borne pathogens, Sclerotium rolfsii, Fusarium oxysporum and Fusarium solani (local isolates) cultures and similarly Trichoderma harzianum (native isolate of DRYSRHU) culture maintained at Biocontrol Laboratory of Horticulture College and Research Institute, Anantharajupet, were used for the antagonistic studies. Trichoderma harzianum was screened for their antagonistic activity through dual culture method on potato dextrose agar (PDA) plates, against these pathogens. In this method, culture discs of $5 \mathrm{~mm}$ each, cut from the margins of actively growing cultures of antagonistic and pathogen, were placed at opposite points in petriplate. Control plates were maintained for Trichoderma harzianum and pathogen and three replications were maintained for each treatment and the petriplates were incubated at $28 \pm 1^{\circ} \mathrm{C}$ for observation. Radial growth of Trichoderma harzianum and pathogen was observed for each treatment up to 7 days of incubation and the percent growth inhibition (I) of pathogen was calculated using the formula (Vincent, 1947).

$\mathrm{I}(\%)=\mathrm{C}-\mathrm{T} / \mathrm{C} \times 100$

Where

$\mathrm{I}=$ Percent inhibition of pathogen by antagonistic.

$\mathrm{C}=$ Radial growth $(\mathrm{cm})$ in control.

$\mathrm{T}=$ Radial growth $(\mathrm{cm})$ in treatment.

\section{Shelf life study in different oil formulations}

Two grams of dry spore was aseptically transferred into pre-sterilized $100 \mathrm{ml}$ of liquid carrier and stirred for better spore suspension. Five different liquid carriers viz., paraffin oil + glycerol (1:1) ratio (T1), paraffin oil + soybean oil (1:1)ratio (T2), soybean oil + glycerol (1:1) ratio (T3), paraffin oil (T4) and soybean oil(T5) were used for the study.

The oils were kept at room temperature and the product was serially diluted to obtain $10^{7}$ concentration and $1 \mathrm{ml}$ was poured in sterilized Petriplates and thereafter, potato dextrose agar medium was poured @ $20 \mathrm{ml} /$ plate. Plates were rotated horizontally for uniform distribution of inoculums and incubated at $28 \pm 1^{\circ} \mathrm{C}$ and colony forming units were recorded at every week interval (Sathiyaseelan et al., 2009). 


\section{Results and Discussion}

\section{Bioefficacy of Trichoderma harzianum}

Antagonistic effect based on the dual culture studies indicated that $T$. harzianum significantly inhibited the mycelial growth of plant pathogens (Table 1). The inhibition percent was 56.7 with clear inhibition zones in Fusarium solani, whereas highest percent inhibition of 66.60 was observed with Sclerotium rolfsii at an incubation period of 7 days, but only 30.90 percent inhibition was recorded with Fusarium oxysporum on $7^{\text {th }}$ day. Susanto et al., (2005) documented highest inhibition capacity of $97.8 \%$ in dual culture analysis when Trichoderma harzianum used as antagonistic fungi. The antagonistic activity of $T$. viride was effective against Rhizoctonia solani (54.91\% inhibition) followed by Macrophomina phaseolina (39.39\% inhibition), Aspergillus flavus (37.11\% inhibition) and inhibition of $28.40 \%$ against Fuasarium carthami as recorded by Sathiyaseelan et al., (2009).

Table.1 Bio-efficacy of Trichoderma harzianum against fungal pathogens

\begin{tabular}{|l|c|c|c|}
\hline \multirow{2}{*}{ Antagonist } & \multicolumn{3}{|c|}{ Percent inhibition over control } \\
\cline { 2 - 4 } & Sclerotium rolfsii & Fusarium oxysporum & Fusarium solani \\
\hline $\begin{array}{l}\text { Trichoderma harzianum } \\
\text { (DrYSRHU) }\end{array}$ & 66.60 & 30.90 & 56.70 \\
\hline
\end{tabular}

Table.2 Oil based formulation of Trichoderma harzianum

\begin{tabular}{|l|c|c|c|c|c|}
\hline \multirow{2}{*}{ Interval } & \multicolumn{6}{|c|}{ Shelf life of Trichoderma harzianum in oil formulations (cfu) } \\
\cline { 2 - 6 } & $\begin{array}{c}\text { Paraffin oil } \\
\text { glycerol (1:1) }\end{array}$ & $\begin{array}{c}\text { Paraffin oil } \\
\text { soybean oil (1:1) }\end{array}$ & $\begin{array}{c}\text { Soybean oil } \\
\text { glycerol (1:1) }\end{array}$ & Paraffin oil & Soybean oil \\
\hline O day & $4.9 \times 10^{9}$ & $4.9 \times 10^{9}$ & $4.9 \times 10^{9}$ & $4.9 \times 10^{9}$ & $4.9 \times 10^{9}$ \\
\hline $7^{\text {th }}$ day & $6.4 \times 10^{8}$ & $39.2 \times 10^{8}$ & $23 \times 10^{8}$ & $47 \times 10^{8}$ & $40 \times 10^{8}$ \\
\hline $\mathbf{1 4}^{\text {th }}$ day & $5.8 \times 10^{4}$ & $5.0 \times 10^{7}$ & $9.5 \times 10^{7}$ & $40 \times 10^{8}$ & $34 \times 10^{8}$ \\
\hline $\mathbf{2 1}^{\text {st }}$ day & $6.5 \times 10^{3}$ & $7.9 \times 10^{4}$ & $7.6 \times 10^{5}$ & $39 \times 10^{8}$ & $27 \times 10^{8}$ \\
\hline $\mathbf{2 8}^{\text {th }}$ day & $4.0 \times 10^{3}$ & $8.4 \times 10^{3}$ & $4.3 \times 10^{4}$ & $35 \times 10^{8}$ & $15 \times 10^{8}$ \\
\hline $\mathbf{3 5}^{\text {th }}$ day & $2.0 \times 10^{3}$ & $6.7 \times 10^{2}$ & $2.1 \times 10^{2}$ & $30 \times 10^{8}$ & $5.7 \times 10^{8}$ \\
\hline $\mathbf{4 2}^{\text {nd }}$ day & $1.0 \times 10^{3}$ & $3.2 \times 10^{2}$ & Nil & $28 \times 10^{8}$ & $24 \times 10^{7}$ \\
\hline $\mathbf{4 9}^{\text {th }}$ day & Nil & $1.1 \times 10^{2}$ & Nil & $25 \times 10^{8}$ & $7.0 \times 10^{7}$ \\
\hline $\mathbf{5 6}^{\text {th }}$ day & Nil & Nil & Nil & $20 \times 10^{7}$ & $2.1 \times 10^{6}$ \\
\hline
\end{tabular}

Oil based formulation of Trichoderma harzianum

Results indicated that on 0 day, the cfu count was $4.9 \times 10^{9}$ in all oils whereas on $7^{\text {th }}$ day, gradual increase in cfu was observed in all oils with highest cfu colonies in paraffin oil $\left(47 \times 10^{8} \mathrm{cfu} / \mathrm{ml}\right)$ followed by soybean oil $\left(40 \times 10^{8} \mathrm{cfu} / \mathrm{ml}\right)$, paraffin oil + soybean oil $\left(39.2 \times 10^{8} \mathrm{cfu} / \mathrm{ml}\right)$, soybean oil + glycerol $\left(23 \times 10^{8} \mathrm{cfu} / \mathrm{ml}\right)$ and lowest $\mathrm{cfu}$ colonies in paraffin oil + glycerol $\left(6.4 \times 10^{8} \mathrm{cfu} / \mathrm{ml}\right)$. Only paraffin oil and soybean oils recorded highest cfu colonies with $40 \times 10^{8}$ and $34 \times 10^{8} \mathrm{cfu}$ colonies, respectively on $14^{\text {th }}$ day whereas on $28^{\text {th }}$ day all oil based formulations showed decrease in cfu except in paraffin oil with 35 $\mathrm{x} 10^{8}$. Similar trend in observation with respect to cfu was recorded on $35^{\text {th }}$ day i.e. 30 x $10^{8} \mathrm{cfu}$ in paraffin oil followed by $5.7 \times 10^{8}$ 
in soybean oil, $2.0 \times 10^{3}$ in paraffin oil + glycerol (1:1), $6.7 \times 10^{2}$ in paraffin oil + soybean oil $(1: 1)$ and $2.1 \times 10^{2}$ soybean oil + glycerol (1:1). Complete absence of Trichoderma harzianum colonies were noticed only in soybean oil + glycerol on $42^{\text {nd }}$ day but in other oils, cfu were observed viz., $28 \times 10^{8}$ in paraffin oil, $24 \times 10^{7}$ in soybean oil, $1.0 \times 10^{3}$ in paraffin oil + glycerol $(1: 1)$ and $3.2 \times 10^{2}$ in paraffin oil + soybean oil (1:1) but on $49^{\text {th }}$ day, colonies could be recorded only in paraffin oil, soybean oil, paraffin oil + soybean oil. In the last day of observation i.e. on $56^{\text {th }}$ day, only in paraffin oil and soybean oil T. harzianum colonies i.e. 20x $10^{7}$ and $2.1 \times 10^{6}$, respectively could be counted indicating that these oils could retain the spore viability for longer period compared to other oils and its combination used in the studies but higher colonies were noted in former oil only (Table 2).

The work carried out by Sathiyaseelan et al., (2009) on shelf life supported our findings that Trichoderma viride in paraffin oil was better than other formulation with $28 \times 10^{8}$ $\mathrm{cfu} / \mathrm{ml}$ followed by soya bean oil with $6 \times 10^{7}$ $\mathrm{cfu} / \mathrm{ml}$ at $49^{\text {th }}$ day as compared to absence of colonies were observed in soybean oil + glycerol (1:1), paraffin oil + glycerol (1:1) and paraffin oil + soybean oil $(1: 1)$ at $35^{\text {th }}$, $42^{\text {nd }}$ and $49^{\text {th }}$ day, respectively.

In conclusion the combination of Trichodermna harzianum in paraffin oil retains the spore viability of antagonistic fungi for longer period as compared to other oils.

\section{Acknowledgements}

The authors thank National Horticulture Mission (NHM), GOI and Dr. YSRHU for providing funding for establishment of BioControl Laboratory. Thanks are also due to Senior Scientist (Hort) and Head, HRS, Ananthrajupeta for encouragement to carry out this work.

\section{References}

Bhai, R.S., J. Thomas and Naidu, R. 1994. Evaluation of carrier media for field application of Trichoderma sp. in cardamom soils. J. Plant. Crops, 22: 50-52.

Baker, K.F. and Cooke, R.J. 1974. Biological control of plant pathogens. W.H. Freeman Press, San Francisco.

Dluzniewska, J. 2003. Reaction of fungi Trichoderma genus to selected abiotic factors. Elec. J. Polish Agr. Uni. Agron., 6(2): 04.

Howell, C.R., L.E. Hanson, R.D. Stipanovic and Puckhaber, L.S. 2000. Induction of terpenoid synthesis in cotton roots and control of Rhizoctonia solani by seed treatment with Trichoderma virens. Phytopathol., 90: 248-252.

Janisiewicz, W.J. and Jeffers, S.N. 1997. Efficacy of commercial formulation of two bio fungicides for control of blue and gray mold of apples in cold storage. Crop Prot., 16: 629-633.

Jegathambigai, V., R.S.W. Wijeratnam and Wijesundera, R.L.C. 2010. Effect of Trichoderma spp. on Sclerotium rolfsii, the causative agent of collar rot on Zamiculcas zamiifolia and farm method to mass produce Trichoderma species. Plant Pathol. J., 9: 47-55.

Lewis, J.A. and Papavizas, G.C. 1987. Reduction of inoculum of Rhizoctonia solani in soil by germlings of Trichoderma hamatum. Plant Pathol., 36: 438-446.

Naseby, D.C., J.A. Pascual and Lynch, J.M. 2000. Effect of five Trichoderma strains on plant growth, Pythium ultimum populations, soil microbial communities and soil enzyme activities. J. Appl. Microbiol., 88: 161-169.

Sarma, Y.R. and Anandaraj, M. 1998. In: 
Development, production and demonstration of biocontrol agents under integrated pest management, Project report for DBT Sponsored Scheme 1994-1993), Indian Institute of Spices Research, Kozhikode.

Sathiyaseelan, K., P. Sivasakthivelan and Lenin. G. 2009. Evaluation of antagonistic activity and shelf life study of Trichoderma viride. Botany Res. Int., 2(3): 195-197.

Sivan, I., Chet. 1986. Biological control of Fusarium spp. in cotton, wheat and muskmelon by Trichoderma harzianum J. Phytopathol., 116: 39-47.
Susanto, A., P.S. Sudharto and Purba, R.Y. 2005. Enhancing biological control of basal stem rot disease (Ganoderma boninense) in oil palm plantations. Mycopathol., 159:153-157.

Vincent, J.M. 1947. Distortion of fungal hyphae in the presence of certain inhibitors. Nature, 159: 850-850.

Zaidi, N.W and Singh, U.S. 2004. Development of improved technology for mass multiplication and delivery of fungal (Trichoderma) and bacterial (Pseudomonas) biocontrol agents. $J$. Mycol. and Pl. Path., 34(3): 732-41.

\section{How to cite this article:}

Srinivasa Reddy, D., Naveena Haritha and Pushpa Latha, M. 2017. Antagonistic Activity and Shelf Life Study of Trichoderma harzianum (Rifai). Int.J.Curr.Microbiol.App.Sci. 6(7): 26112615. doi: https://doi.org/10.20546/ijcmas.2017.607.308 